\title{
Thermal Spray Techniques for Developing a Carbide Coating
}

\author{
Dhaval Patel, Pina Bhatt, Ragesh Bateriwala
}

\begin{abstract}
In the industries, different components of different materials are being used in a different service environment, in the view of this requirement day by day specific surface properties are demanding by industries to enhance the product life cycle. A range of surface protection techniques are accessible for various apps with a common goal of protecting a part or object that is subjected to a chemical environment. This process leads to decreases manufacturing cost as no need to fabricate a new part. Commercially Coating materials include strong and rigid metal alloys, ceramics and polymers, composites material are available for durable protection. There are different methods of thermal spray such as flame spray, D-gun spray, high-velocity oxy-fuel Spray, Plasma Spray, and cold spray process have been introduced and investigated. Even though each method has distinct values and procedures that limit their applications. However, there are many things to understand that are used to overcome the lack of thermal spray coating methods by combining process parameters. In this article, we have discussed the various coating materials have been used commercially, and further categorized and compared various thermal spray processes.
\end{abstract}

Keywords: Carbide Coating, Thermal Spray, HVOF Spray, Cold spray.

\section{INTRODUCTION}

D ifferent material possesses different properties, so it is not feasible to have distinctive features for a single product to fulfill the demands of the current profession. Therefore, a composite base material system with a separate protective surface layer in structure and/or chemical composition can be an ideal choice when incorporating material features [1]. In an oxidizing and corrosive environment, structural materials and parts of gas turbine motors work under very aggressive circumstances, characterized by elevated temperature and mechanical load. Inlet temperatures are approximately $1400-1500{ }^{\circ} \mathrm{C}$ in stationary gas turbines. Cemented carbides are the types of ceramic-metal composites which possess an excellent combination of hardness, wear-resistance, and toughness at high temperature [2]-[4].

The basic construction blocks of thermal spray layer are formed by fast solidification and the trying to stack of molten metals or ceramic splats through the spray torches by a series of different passes [5],[6]. The coating characteristics lead from the conceptual relationship of three inputs, i.e. the dissemination of feedstock and related attributes, the heat

Revised Manuscript Received on October 31, 2019.

* Correspondence Author Ahmedabad, Gujarat, India. Email: dhavalpatelmechanical@gmail.com

Pina Bhatt, Dept. of Mechanical Engg, Aditya Silver Oak Institue of Technology, Ahmedabad, Gujarat, India. Email: pmbhatt15@gmail.com

Ragesh Bateriwala, Dept. of Mechanical Engg, Keepsake Engineering consultancy Pvt Ltd., Gujarat, India. Email: rbateriwala@keepsake.in
Dhaval Patel *, Dept. of Mechanical Engg, L D College of Engineering,

source velocity and temperature, and the temperature and velocity of the particles[7], [8]. The oxides and voids remaining in the coatings (which include cracks and porosity) can be regulated by the types and sizes of feedstock and thermal spray process used [9].

This review paper is focused on the various processes used for the coating by using thermal energy is called thermal spray process. It is grouped on the basis of different types of thermal spray processes and carbide coating material.

\section{Feedstock}

A raw material is to be deposits called feedstock is used for products that are fed into a spray torch. it can be categorized into three groups for heat spray processes: (a) Powder (b) cords and rods and (c) Suspended particle. Powder feedstock is used on a large scale due to positive review and easy manufacturing and economic product. Table 1 demonstrates the suggestions for commercial powder feedstocks and related thermal spray procedures. The main features of all the feedstocks depend on their production procedures [6],[10]

In addition to chemical composition, the important characteristics of the thermal spray feedstock include particle size distribution, overall mass, morphology and particle size [11]. For example, tungsten carbide may have different features depending on the manufacturing method of the feedstock, similar powder with identical chemical constituents. Fig. 1 shows relationships between the powder manufacturing processes, porosities, and grain fineness.

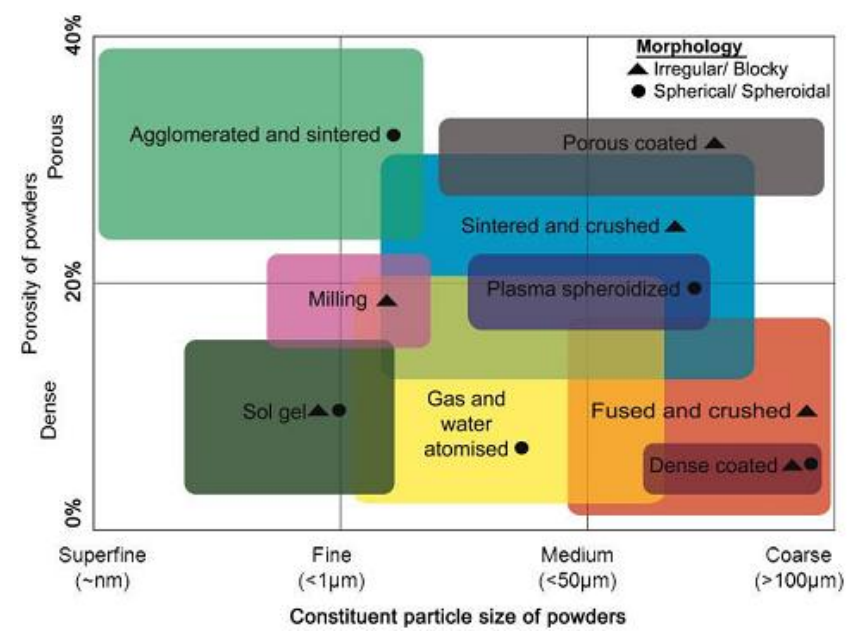

Fig. 1. Powder manufacturing techniques and feedstock porosity and size classifications[12] 
Thermal Spray Techniques for Developing a Carbide Coating

Table I Thermal Spray Feedstock Powder commercially available \$

\begin{tabular}{|c|c|c|c|c|}
\hline Type of Layer & Compositions of material & Methods of use & Particle Dimensions & Freezing temp. (Appx. 0C) \\
\hline Metallic & $\begin{array}{c}\mathrm{Al}, \mathrm{Al}-\mathrm{Si} \\
\mathrm{Cu}, \mathrm{Cu}-\mathrm{Ni}, \mathrm{Cu}-\mathrm{Al} \\
\mathrm{Ti}, \mathrm{Ta} \\
\mathrm{FeCr}, \mathrm{FeCrNiMo} \\
\mathrm{FeCr} \text { based } \\
\mathrm{MCrAlY}(\mathrm{M}=\mathrm{Co}, \mathrm{Ni}, \mathrm{Fe}) \\
\mathrm{Mo}, \mathrm{Mo}-\mathrm{based} \\
\mathrm{Ni}, \mathrm{Ni}-\mathrm{Cr}, \mathrm{Ni}-\mathrm{Al} \text {, and } \\
\mathrm{Ni}-\mathrm{Based}\end{array}$ & $\begin{array}{l}\text { APS } \\
\text { CS } \\
\text { FS } \\
\text { HVOF } \\
\text { APS } \\
\text { CS } \\
\text { FS } \\
\text { VPS } \\
\text { CS } \\
\text { APS } \\
\text { HVOF } \\
\text { FS } \\
\text { APS } \\
\text { HVOF } \\
\text { VPS } \\
\text { APS } \\
\text { APS } \\
\text { FS } \\
\text { CS } \\
\text { HVOF } \\
\text { VPS }\end{array}$ & $\begin{array}{c}-90+45[-170+325 \text { mesh }] \\
-45[-325 \text { mesh }] \\
-90+45[-170+325 \text { mesh }] \\
-88+31[-170 \text { mesh }+31] \\
-75+45[-200+325 \text { mesh }] \\
-35+15[-400 \text { mesh }+15] \\
-75+45[-200+325 \text { mesh }] \\
-90+22[-170 \text { mesh }+22] \\
-63[-230 \text { mesh }] \\
-106+45[-140+325 \text { mesh }] \\
-45+5.5[-325 \text { mesh }+5.5] \\
-125+45[-120+325 \text { mesh }] \\
-38+5[-400 \text { mesh }+5] \\
-45+22[-325 \text { mesh }+22] \\
-38+5[-400 \text { mesh }+5] \\
-90+38[-170+400 \text { mesh }] \\
-106+45[-140+325 \text { mesh }] \\
-125+45[-120+325 \text { mesh }] \\
\quad-30+10 \\
-45+11[-325 \text { mesh }+11] \\
-37[-400 \text { mesh }]\end{array}$ & $\begin{array}{c}6600 \mathrm{C}[1220 \mathrm{~F}] \\
\mathrm{Cu} ; 1083 \text { 0C }[1981 \mathrm{~F}] \\
\mathrm{Cu}-\mathrm{Al} ; 10400 \mathrm{C}[1904 \mathrm{~F}] \\
\mathrm{Cu}-\mathrm{Ni} ; 12050 \mathrm{C}[2201 \mathrm{~F}] \\
\mathrm{Ti} ; 16650 \mathrm{C}[3029 \mathrm{~F}] \\
815-12000 \mathrm{C}[1449-2192 \mathrm{~F}] \\
>11200 \mathrm{C}[>2048 \mathrm{~F}] \\
\text { 26200C }[4748 \mathrm{~F}] \\
1232-14530 \mathrm{C}[2250-2647 \mathrm{~F}]\end{array}$ \\
\hline $\begin{array}{l}\text { Composite } \\
\text { (Metallic) }\end{array}$ & $\begin{array}{l}\text { Al- Si based abradables } \\
\text { CoNi-based abradables } \\
\text { Ni-based Material } \\
\mathrm{Cu}-\mathrm{Al} \text { Bronze based }\end{array}$ & $\begin{array}{l}\text { APS } \\
\text { FS } \\
\text { APS } \\
\text { FS } \\
\text { HVOF } \\
\text { APS } \\
\text { FS }\end{array}$ & $\begin{array}{l}-150+7.8[-100 \text { mesh }+7.8] \\
-125+5[-120 \text { mesh }+5] \\
-176+11[-80 \text { mesh }+11] \\
-90+30[-170 \text { mesh }+30] \\
-45+15[-325 \text { mesh }+15] \\
-125+11[-12 \text { mesh }+11] \\
-106+45[-140+325 \text { mesh }]\end{array}$ & $\begin{array}{l}\text { 5770C }[1071 \mathrm{~F}] \\
11400 \mathrm{C}[2084 \mathrm{~F}] \\
14530 \mathrm{C}[2647 \mathrm{~F}] \\
10400 \mathrm{C}[1904 \mathrm{~F}]\end{array}$ \\
\hline Inter-metallic & $\begin{array}{l}\text { CoCrNiWC, CoCr- based } \\
\text { NiCrSiB, NiCrSiB- based } \\
\text { Self fluxing alloys }\end{array}$ & $\begin{array}{l}\text { HVOF } \\
\text { APS } \\
\text { FS } \\
\text { FS } \\
\text { HVOF }\end{array}$ & $\begin{array}{c}-45+11[-325 \text { mesh }+11] \\
-45+15[-325 \text { mesh }+15] \\
-75+45[-200+325 \text { mesh }] \\
-106+45[-140+325 \text { mesh }] \\
-45+11[-325 \text { mesh }+11]\end{array}$ & $\begin{array}{l}\text { 1230-16000C }[2246-2912 \mathrm{~F}] \\
10500 \mathrm{C}[1922 \mathrm{~F}]\end{array}$ \\
\hline Cermet & $\begin{array}{c}\text { Mo-Mo2C } \\
\text { CrC-NiCr,CrC Ni-based } \\
\text { WC-Co, WC-Ni, } \\
\text { WC- based }\end{array}$ & $\begin{array}{l}\text { APS } \\
\text { APS } \\
\text { HVOF } \\
\text { FS } \\
\text { APS } \\
\text { HVOF } \\
\text { FS }\end{array}$ & $\begin{array}{l}-90+45[-170+325 \text { mesh }] \\
-53+11[-270 \text { mesh }+11] \\
-38+10[-400 \text { mesh }+10] \\
-53+11[-270 \text { mesh }+11] \\
-53+11[-270 \text { mesh }+11] \\
-45+11[-325 \text { mesh }+11] \\
-90+45[-170+325 \text { mesh }]\end{array}$ & $\begin{array}{r}26200 \mathrm{C}[4748 \mathrm{~F}] \\
19300 \mathrm{C}[3506 \mathrm{~F}] \\
1250-14800 \mathrm{C}[2280-2696 \mathrm{~F}]\end{array}$ \\
\hline Ceramic & $\begin{array}{c}\mathrm{A} 12 \mathrm{O} 3, \mathrm{~A} 2 \mathrm{O} 3-\mathrm{TiO} 2, \\
\mathrm{Cr} 2 \mathrm{O} 3, \mathrm{Cr} 2 \mathrm{O} 3-\mathrm{TiO} 2 \\
\mathrm{Cr} 2 \mathrm{O} 3-\mathrm{TiO} 2-\mathrm{SiO} 2 \\
\mathrm{TiO} 2 \\
\mathrm{ZrO} 2-\mathrm{Y} 2 \mathrm{O} 3, \mathrm{ZrO} 2-\mathrm{MgO}, \mathrm{Zr} \\
\text { O2-based }\end{array}$ & $\begin{array}{l}\text { APS } \\
\text { FS } \\
\text { APS } \\
\text { FS } \\
\text { APS } \\
\text { FS } \\
\text { APS }\end{array}$ & $\begin{array}{r}-45+5[-325 \text { mesh+5 }] \\
-45+5[-325 \text { mesh }+5] \\
-106+30[-140 \text { mesh }+30] \\
-125+7.8[-120 \text { mesh }+7.8] \\
-88+7.8[-170 \text { mesh }+7.8] \\
-88+7.8[-170 \text { mesh }+7.8] \\
-125+11[-170 \text { mesh }+11]\end{array}$ & $\begin{array}{l}20540 \mathrm{C}[3729 \mathrm{~F}] \\
24350 \mathrm{C}[4415 \mathrm{~F}] \\
18430 \mathrm{C}[3349 \mathrm{~F}]\end{array}$ \\
\hline
\end{tabular}

\$ Data are collected from the various powder manufacturer's catalogs.

Traditional powder size ranges used in the thermal spray for feedstock are from 15 to 45 um [mesh-325 + 15 um] (measured like a fine cut), from 45 to 106 um [ mesh $-140+$ 325 ] (coarse cut) and other sizes of 5 to 22 um [ mesh-500 + $5 \mathrm{um}$ ] identified as a narrow cut. Generally speaking, a small distribution of the powder size will generate more homogeneous coating characteristics [13], [14]. The 20-60um [ mesh $-230+630$ ] particle size ranges are preferred to form coatings with excellent integrity. In addition, the latest sol-gel technology has been discovered and can also form fine-grained, dense coatings with excellent mechanical attributes[15], [16].

Due to their distinct particular masses, the individual particle momentums would be varied, So the particle transmission routes in the spray jet often demonstrate excellent propagation. Thus, the final impression on speeds and conveyed temperatures to the feedstock particles by the vigorous spray jet will be exaggerated and the coating properties will change [17].

Hollow spherical powders (HOSP) have excellent flow characteristics and their less mass allows the high-temperature plasma spray jet to melt consistently [18]. 
Fig. 1 shows the amount of porosity of the feedstock differs with the techniques of powder manufacturing. The feedstock morphologies can be defined by circularity shape factor.

$$
\text { Circularity shape factor }=4 \pi \frac{A p}{P_{f}^{2}}
$$

Where $A_{p}=$ Based on the proposed feedstock region and

$$
P_{f}=\text { Feedstock's perimeter }
$$

circularity shape factor ranges between 0.16 and 1.00, 0.16 for granular / angled feedstock and 1.00 for spherical particles. The classification of SA: V (Proportion of the Surface area to volume) and circularity factor of powders produced with different manufacturing techniques as indicated in fig. 2. This is observed that spherical particles of same size have less significance (SA: V) than the blocked feedstock. And agglomerated powders have a larger surface than spherical and dense powders. Because of the rise in the surface area, materials with a large (SA: V) value are quickly heated and favor heat transfer processes.

Other variable affects the velocity of feedstock grain impingement and the temperature is the morphological characteristics of particles and how much porous. Coating from a feedstock of the similar chemical composition but different morphology will give distinct comparable properties [19].

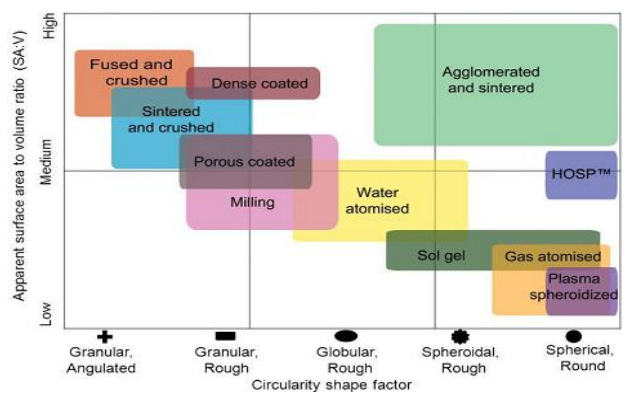

Fig. 2 Classification of SA: $\mathrm{V}$ by quantity in relation to the shape factor [12]

\begin{tabular}{|c|c|c|}
\hline $\begin{array}{c}\text { Energy } \\
\text { input }\end{array}$ & Variations & Spray Techniques \\
\hline $\begin{array}{l}\text { Combustion } \\
\text { heat sources }\end{array}$ & $\begin{array}{l}\text { Non-Continuous } \\
\text { Explosive } \\
\text { Non-Continuous } \\
\text { Explosive } \\
\text { DC Arc }\end{array}$ & $\begin{array}{c}\text { Flame sprayed, } \\
\text { High-Velocity } \\
\text { Oxygen-Fuel Spray } \\
\text { (HVOF) Process } \\
\text { Detonation Gun Spray } \\
\text { method } \\
\text { AS, APS, VPS }\end{array}$ \\
\hline \multirow{2}{*}{ Electric Arc } & Pulsing Arc & $\begin{array}{l}\text { Pulsing arc, Vollrathet al. } \\
\text { (1992) Whiterspoon et al. } \\
\text { (2004) defined torches }\end{array}$ \\
\hline & $\begin{array}{c}\text { HF (RF) glow } \\
\text { discharge }\end{array}$ & $\begin{array}{c}\text { RF plasma torch (Mailhot } \\
\text { et al., 1998; Bouyer et al., } \\
2003)^{\mathrm{b}}\end{array}$ \\
\hline $\begin{array}{c}\text { Gas } \\
\text { Expansion }\end{array}$ & Cold spray & $\begin{array}{c}\text { Cold } \\
\text { Spraying, Hypersonic } \\
\text { spray or kinetic spray }\end{array}$ \\
\hline
\end{tabular}

Table 2 Thermal Spray techniques[20]

b See the catalog of Tekna, Sherbrook, Canada.

\section{Thermal Spray Processes}

Thermal spray is a technique that deposits particulate molten, semi-molten or solid on a material being coated. Spraying method is subsequently a direction to generate such particles 'stream'. The Layer can be produced when the particles can deform plastically with the substrate at high impact, which is possible only If fused or solid enough and fast enough. When they occur in a gas stream, their heating and/or acceleration are suitable. Therefore, An academic categorization of spray techniques is based on how such streams are generated. Table 2 explains how thermal spray procedures are classified. Fig. 3 shows the relationship between the particle temperature, typical feedstock size, and achievable particle velocity.

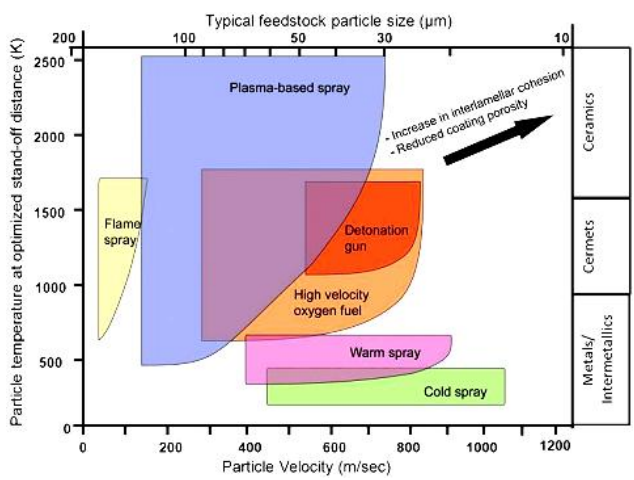

Fig. 3 Categorization of the thermal spraying method with reference to the temperature of the particles, Velocity of Particle and the average size of the feedstock.[12]

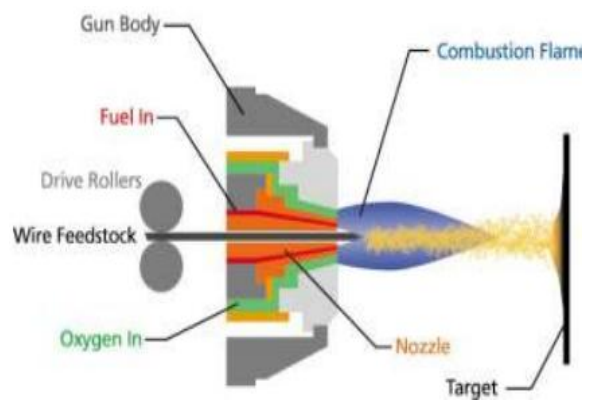

Fig. 4 Flame Spray Process - Schematic Diagram.[24]

\section{Fuel Gas Spraying Methods:}

\section{A. Flame Spray Method:}

The method of flame spray (FS) was first defined in the 1912 patent of M.U Scoop [21] and displayed the basic fuel combustion method. This method now it reports $30 \%$ to $45 \%$ of the global thermal spraying sector [22]. Flame spray processes, as shown in fig.4. Fuel and oxygen streams are combusted horizontally at end of the nozzle and feedstock are axially inserted into the flames via carrier gas, For example, argon, nitrogen, etc. Coating 
Thermal Spray Techniques for Developing a Carbide Coating

Table 3 Normal fuel gas properties for flame spraying technique arranged in the ascending flame temperature order [23]

\begin{tabular}{|c|c|c|c|c|c|}
\hline \multirow[t]{2}{*}{ Type of Fuel } & \multirow{2}{*}{$\begin{array}{l}\text { Chemical } \\
\text { Equation }\end{array}$} & \multirow{2}{*}{$\begin{array}{l}\text { Max. } \quad \text { Flame } \\
\text { Temp. K [F] }\end{array}$} & \multirow{2}{*}{$\begin{array}{l}\text { Calorific value of } \\
\text { fuel } \\
\mathrm{M} \mathrm{Jm}^{-3}\left[\mathrm{Btu} \mathrm{ft}^{-3}\right]\end{array}$} & \multicolumn{2}{|c|}{ Oxygen/fuel ratio require } \\
\hline & & & & Max. S/c Temp. & Stoichiometry \\
\hline Propane & $\mathrm{C}_{\mathrm{g}} \mathrm{H}_{\mathrm{g}}$ & $3101[5122]$ & $93.2[2501]$ & 4.5 & 5.0 \\
\hline Hydrogen & $\mathrm{H}_{2}$ & 3129 [5173] & $10.8[290]$ & 0.42 & 0.5 \\
\hline Propylene & $\mathrm{C}_{\mathrm{a}} \mathrm{H}_{6}$ & 3169 [5245] & $27.6[741]$ & 3.4 & 4.5 \\
\hline Ethylene & $\mathrm{C}_{2} \mathrm{H}_{4}$ & 3197 [5295] & 59.5 [1597] & 2.4 & 3.0 \\
\hline Acetylene & $\mathrm{C}_{2} \mathrm{H}_{2}$ & $3433[5720]$ & $56.4[1513]$ & 1.5 & 2.5 \\
\hline
\end{tabular}

material that wishes to be coated on a substrate may be in the form of powder, sticks or wires. Fuel gases are provided at low pressure and combustion happens outside the torch at atmospheric pressure, it results in lowest particle acceleration.

\section{B. D- gun Method:}

A method developed by Union Carbide Inc. in the 1950s is known as detonation gun (D-Gun $®)$ process [25]. Fig. 5 demonstrates the Schematic diagram of D-Gun includes long, water-cooled barrels with 25 mm ID (schwarz 1980).

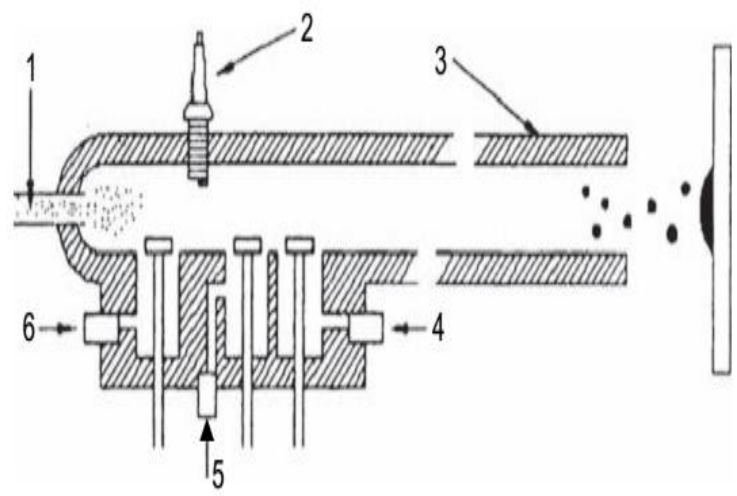

Fig. 5 Schematic Diagram of D-Gun Process:(1) Powder injection; (2) spark plug; (3) gun barrel; $(4,6)$ Oxygen input; (5) nitrogen input [26].

The working principle of the gun is that a heavy-pressure wave is generated by a repeated ignition of the fuel blend, generally acetylene and oxygen inside a long, narrow pipe. TV sources are used for heat and detonation pressure surges, which accelerate the particles to the substrates at 3 to $15 \mathrm{~Hz}$. This is the only reason to use the D-Gun method to obtain high bond strength dense coatings [27], [28]. D-Gun method offers excellent wear resistance relative to plasma spray coatings to abrasion and erosion [29].

Detonation wave, powder, powder feed rate, the composition of carrier gas, spray distance are principle Process parameters of D-gun method [26].

\section{High-Velocity Oxygen Fuel sprays (HVOF) Process:}

Browning and his collaborators used high kinetic energy in the form of high gas pressure and controlled heat output to develop dense and low porosity coating in the early 1980s, a high-velocity oxy-fuel spray process that became popular [30].
The flamming temperature exceeds $2900 \mathrm{~K}$ depending on the type of fuel gas and the oxygen/fuel ratio shown in Table 2 [23].

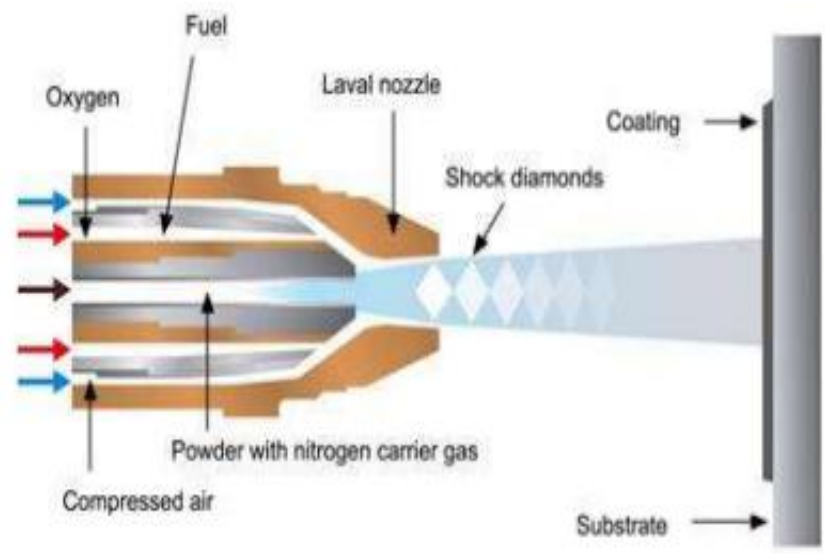

Fig. 6 Schematic HVOF process diagram [24]

As illustrated in fig. 6, the combustion chamber is provided with HVOF process fuel and oxygen concurrently with the feedstock material. Combustion of fuels created elevated temperature and pressure in the combustion chamber, resulting in a high-velocity jet of gasses passing through the nozzle. flame temperature ranges from $25000 \mathrm{C}$ to $32000 \mathrm{C}$ totally depends on fuel type, fuel/oxygen ratio and gas pressure. The particles of powder will melt partly or completely depends on the particle dwelling time, melting temp and coefficient of thermal conductivity of powder [24].

New variants of HVOF system have been introduced easily by changing the fuel gas composition to develop good characteristic coatings. Propylene, Propane, Hydrogen or natural gas used in the gas-fueled system and in liquid-fueled system Kerosene is used as fuel [31].

Table 3 demonstrates the torch used for the HVOF method with its oxygen to fuel ratio for ignition according to chronological growth. Depends on fuel gas and torch construction, the flame temperature reaches $4000 \mathrm{~K}$ and the energy are in the order of 80 to $278 \mathrm{~kW}$.

HVOF coatings result in reduced residual stress [32], [33] compared to air plasma spray coatings technique due to layer deposition temperature considerably lesser. 


\section{Thermal Spray Processes based on Electrical ENERGY:}

\section{A. Plasma Spray Process:}

Plasma spray processes used RF Discharge or DC electric arc to produce plasma temperature in the heating region between 6000 and $15000 \mathrm{~K}$, considerably above any material's melting point [34], [35].

The plasma spray schematic diagram is displayed in the fig. 7

[24].Thermal plasmas are categorized as atmospheric plasma spray (APS) technique, vacuum plasma spray (VPS) method or low-pressure plasma spray (LPPS) method and regulated atmospheric plasma spray (CAPS) method in a field of thermal spray.

The momentum given to the particles in flight is influenced by the plasma jet flow[36]. Large Temperature drops in plasma jet and velocity decay as the jet leaves the nozzle. [35] The kinetic energy imparted to powder particles varies according to change in torch design that influences the coating microstructure [37], [38].

Table 4 Properties of typical HVOF spray torch\#

\begin{tabular}{|c|c|c|c|c|c|}
\hline $\begin{array}{c}\text { Torch with Brand Name } \\
\text { (year) }\end{array}$ & Fuel gas & $\begin{array}{l}\text { Flow of Fuel in } \\
\text { Lmin }^{-1}\end{array}$ & $\begin{array}{l}\text { Flow of Oxygen gas } \\
\text { in } \mathrm{Lmin}^{-1}\end{array}$ & $\begin{array}{c}\text { Flow of Air in } \\
\text { Lmin }^{-1}\end{array}$ & $\begin{array}{c}\text { Ratio (Oxygen } \\
\text { to fuel) }\end{array}$ \\
\hline $\begin{array}{c}\text { Jetkote }{ }^{\circledR D e l o r o S t e l l i t e} \\
\text { (1982) }\end{array}$ & $\begin{array}{c}\text { Hydrogen } \\
\text { Propane } \\
\text { Ethylene }\end{array}$ & $\begin{array}{c}432 \\
50 \\
80\end{array}$ & $\begin{array}{l}302 \\
350 \\
337\end{array}$ & $\begin{array}{l}-- \\
-- \\
--\end{array}$ & $\begin{array}{l}0.7 \\
7.0 \\
4.2\end{array}$ \\
\hline Top gun , UTP (1989) & $\begin{array}{c}\text { Hydrogen } \\
\text { Propane } \\
\text { Ethylene }\end{array}$ & $\begin{array}{c}432 \\
50 \\
80\end{array}$ & $\begin{array}{l}217 \\
250 \\
240\end{array}$ & $\begin{array}{l}-- \\
--\end{array}$ & $\begin{array}{l}0.5 \\
5.0 \\
3.0\end{array}$ \\
\hline $\begin{array}{l}\text { DJ2600, Sulzer Metco } \\
\text { (1994) }\end{array}$ & $\begin{array}{l}\text { Hydrogen } \\
\text { Propane } \\
\text { Ethylene } \\
\text { Kerosene }\end{array}$ & $\begin{array}{c}613 \\
189 \\
111 \\
68 \\
\end{array}$ & $\begin{array}{l}214 \\
278 \\
247 \\
240 \\
\end{array}$ & $\begin{array}{l}344 \\
391 \\
360 \\
375 \\
\end{array}$ & $\begin{array}{c}0.47 \\
1.9 \\
2.91 \\
4.67 \\
\end{array}$ \\
\hline JP- 5000®,Praxair (1992) & Kerosene & 0.379 & 876 & -- & $2314 *$ \\
\hline $\begin{array}{l}\text { Workastar }^{\mathrm{TM}} \text {, make by } \\
\text { Sulzer Metco }(2004)\end{array}$ & Kerosene & 0.379 & 876 & -- & $2314 *$ \\
\hline $\begin{array}{l}\text { GTV K2, make by GTV } \\
\text { (2005) }\end{array}$ & Kerosene & 0.379 & 820 & -- & $2204 *$ \\
\hline
\end{tabular}

\# table data is prepared from the different industries catalogs.

* The liquid fuel values are high because the rates of flow of liquid are relatively small.

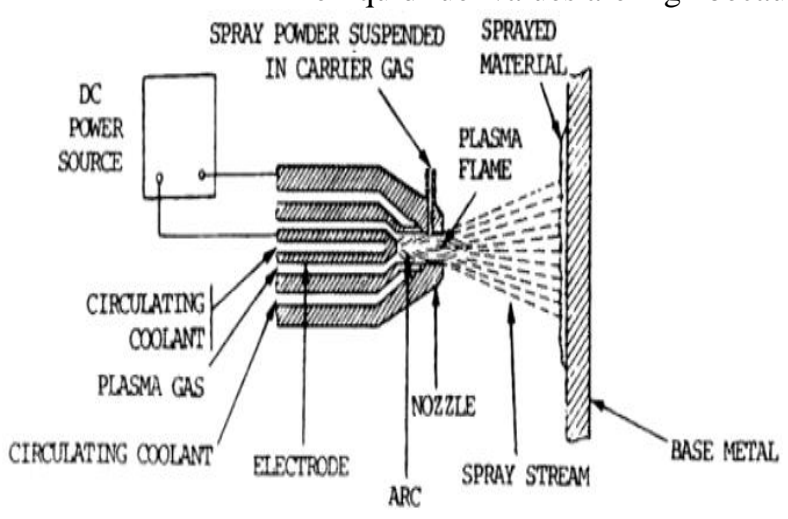

Fig. 7 Plasma Spray method

\section{B. Wire Arc Spray method:}

Spray procedures of the double wire arc (TWA) described in a patent by M.U Schoop in 1910 [39]. It is a reliable, economical and widely used technique for producing a corrosion-resistant layer. The DC electric arc is produced between two consumable electrodes in the shape of wire and high-velocity gas jet transmits the melted metals to the substrate. The arc temperature is approximately $7000 \mathrm{~K}$ which is adequate for melting of electrode. The gas jet is atomized into particles and placed on the substratum.

The wire spray method is demonstrated in fig.8, this method is very much popular due to less operating cost, high deposition efficiency and production rate than plasma or
HVOF process. This process is being used for maintenance of worn parts and outstandingly suitable for the dimensional recovery of worn components and provide the solution on-site [40].

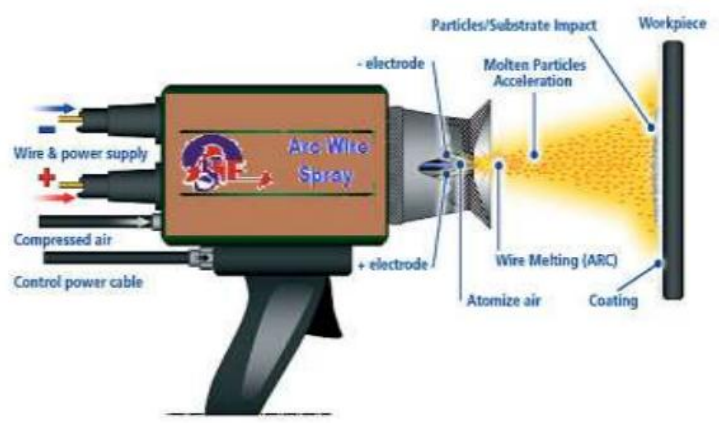

Fig. 8 Wire Spray method[24]

\section{Thermal SPRAY METHODS ARE CATEgORIZED ON THE BASES OF KINETIC ENERGY}

\section{A. Cold Spray method}

Cold spray method categorized under thermal spray was found in the mid-1980s [41]. 
Cold spray is comparatively recent spray method which belongs to a broad group of thermal spray processes in which solid powder particles usually ceramics, metals, composites, etc are accelerated in a converging-diverging nozzle towards the substrate. When the particle reached the supersonic velocity and impinged on a solid surface above a certain minimum level of velocity and at a temperature below the fusion temperature of the powder, the abrasion induced by the metal atoms transformed into particle adhesion [42].

Fig 9 (a \& b) shows the schematic presentation of Cold spray process. The most distinguishing characteristic of the cold spray method is the capability to generate coatings in the temperature ranges of $0-8000 \mathrm{C}$ with preheating a gas, the range is smaller than the temperature of the powder particle [43]. The damaging impacts due to elevated temperatures such as oxidation, decarburization, melting, debonding residual stress and other problems are therefore decreased [6], [44].

\section{B. Carbide Coating material}

The powder material is manufactured by agglomerated and sintering as per coating process requirement and the coating quality by a combination of different carbide particle and metal binder [2].

D. A. Stewart placed conventional and nanocomposite powder HVOF coatings containing 2-5 micron and 70-250 $\mathrm{nm}$ of WC grains. The author said that the coatings differed in the existence and proportion of the existing phases and the extent of decarburization. The author has also noted that W2C is observed in both coatings, whereas $\mathrm{W}$ is discovered only in the deposition of nanocomposite [12].

H. Singh [45] developed WC-12\% Co and $\mathrm{Cr} 3 \mathrm{C} 2-25 \%$ $\mathrm{NiCr}$ coatings by HVOF method with LPG as fuel gas on boiler tube steels with a 350 to $380 \mu \mathrm{m}$ thickness. Coatings have been evaluated with micro-hardness testing and discovered the hardness of $\mathrm{WC}-12 \% \mathrm{Co}$ Coatings have a slightly greater hardness compared to $\mathrm{Cr} 3 \mathrm{C} 2-25 \% \mathrm{NiCr}$ coatings, but all coatings have excellent hardness relative to the base material/substrate. The author has reported that WC $-12 \%$ Co coating have lesser porosity than $\mathrm{Cr} 3 \mathrm{C} 2-25 \%$ $\mathrm{NiCr}$ coating. Both coatings were possessing a high composition of carbides in the matrix due to which high micro-hardness and fewer porosity values were achieved in these coatings.

H.J.C Voorwald deposited WC-17Co and WC-10Co-4Cr coatings by a method of HVOF spray on the AISI 4340 steel and compares the fatigue strength and corrosion strength with and without shot peening. The author concluded that WC coatings give better alternatives to increase the fatigue strength of AISI 4340 steel when compared to chromium electroplated hard material. Further, investigated that shot peening prior to thermal spray shown excellent fatigue strength, Higher axial fatigue strength and corrosion resistance in salt spray exposure for the samples of WC-10Co-4Cr coatings than that of WC-10Co [46].

H.L. Tian has produced a coating of WC- $12 \mathrm{Co}$ with Graphene Oxide(GO) on the AISI 316 stainless steel plates. To deposit the coatings, a Russian D-gun spray device (' ob'type) was used. Phase identifications for WC-12Co Coating and WC-12Co Coating with Graphene Oxide(GO) were performed using X-ray diffraction (XRD) with monochromatic $\mathrm{Cu} \mathrm{K} \alpha$ radiation $(\pi=0.154056 \mathrm{~nm})$. SEM assessed the microstructures and morphologies of sprayed coatings with the as-sprayed condition and the worn surfaces. The authors concluded that, a self-lubricating film formed on the graphene surface during the wear. The friction coefficient was decreased by 28 percent compared to the implementation without graphene [47].

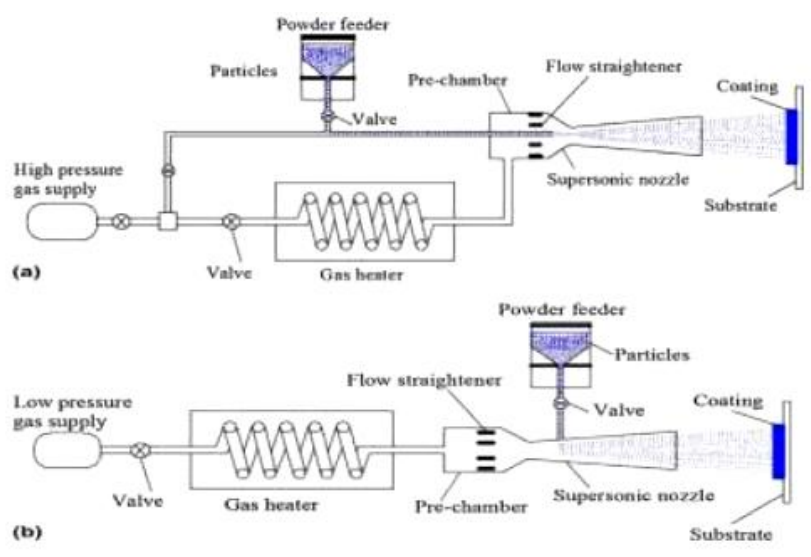

Fig. 9 Schematic diagram of Cold Spray Process (a)
HPCS (b) LPCS [24]

Xiang DING developed a latest type of multi-dimensional WC-10Co4Cr coating material composed of three levels like nano, submicron, and micron $\mathrm{WC}$ and $\mathrm{CoCr}$ alloy was sprayed using a high-velocity oxygen-fuel (HVOF) process. The author further explored the strength of multidimensional WC-10Co4Cr coatings, porosity level, microhardness value, fracture toughness, and cavitation erosion resistance. Further, he tried to compare it with the nanostructured and bimodal coating. The writer noted that the $\mathrm{WC}-10 \mathrm{Co} 4 \mathrm{Cr}$ multidimensional layer shows the greatest resistance to cavitation erosion, which is improved by about $28 \%$ and $34 \%$, respectively, relative to coating with nano particle and bimodal coatings in freshwater [48].

Omar Ali produced WC-coatings by spraying liquid suspension (S-HVOF) and compared the microstructure, hardness and elastic modulus with the coating produced by conventional liquid-fueled HVOF process. The author revealed that the S-HVOF coating elastic modulus was greater than the ordinary HVOF layer, while hardness values were lower than conventional coating. Evidence of micro-cracking and piling was noted in the microstructure assessment of S-HVOF coated layer [49].

The behavior of HVOF thermal spray WC-Co coatings regarding cavitation erosion with Two separate structures (WC-12Co and WC-17Co) on steel (AISI 1008) was explored by Murilo S. Lamana using various fuels. The author discovered that the HVOF-LF method produced higher compressive stress for both compositions due to higher particle velocity and subsequently higher coating density. Cobalt content also exaggerated fracture toughness, due to enhancing the content of matrix phase [50]. 
Vasileios Katranidis, attention provided to the morphological characteristics of recognized WC products of decarburization. The author has used XRD diffractogram to reveal the WC, W2C compositions. The FIB-SEM plasma was used for capturing images from a coating material, with the aim of extracting insights into the 3D structure of the $\mathrm{W} 2 \mathrm{C}, \mathrm{W}$ (metallic) and porosity. The author discovered that semi-carbide (W2C) crystals are shown to develop epitaxially on the affected WC grain and grow with gradually thinning cross-sections radially [51].

M. Aghaie-Khafri produced a Vanadium Carbide coating using a thermal reactive diffusion process on the steel die of DIN 1.2367 material at different temperatures with a powder mixture of ferrovanadium, ammonium chloride, alumina, and naphthalene. The author has used microstructure examination, microhardness testing, X-ray diffraction, and chemical analysis to analyze coatings. Substrate's thickness ranged from 2.3 to $23.2 \mathrm{~mm}$. through the dry wear test, Pin-on Disk test, The author found that vanadium carbide-coated steel is much more wear-resistant than uncoated steel [52].

Swapnil V. Shah used Nd: YAG laser to develop a coating of VC on AISI H13 steel. The author evaluated chemical, structural and mechanical properties through the thermogravimetric analysis, microscopic test and Immersion test in aluminum (molten state). The author found that VCH13 composite coating found significant oxidation resistance at below 800 0C (570-620 0C aluminum die-casting temperature). Relative to the H13 steel, the coating shows great resistance to chemical action by molten aluminum. The main method of a liquid aluminum chemical attack was through the pitting system. Compared to the layer, the pitting was serious in H13 [53].

X.S. Fan [54] prepared vanadium carbide coatings on AISI $\mathrm{H} 13$ steel in a molten salt bath for 1 to $6 \mathrm{~h}$ at $920^{\circ} \mathrm{C}$ and $1000^{\circ} \mathrm{C}$ respectively by thermo-reactive deposition/diffusion method (TRD). Scanning of electron microscopy (SEM), energy dispersive X-ray spectrometry (EDX) and X-ray diffraction (XRD) analysis examined the VC coatings. Equiaxed grains were noted throughout the coatings by the author. The grain size gradually increased to the top surface from the coating - substrate interface. The Author created a connection for the vanadium carbide coatings on AISI H13 steel between the changes of surface thickness (1) with processing period $(\mathrm{t})$ and temperature $(\mathrm{T})$ as shown below:

$$
l^{2}=4.16 \times 10^{-3} e^{(-23971.6 / T)} t
$$

Qianlin Wu has developed a VC-Cr7C3 laser cladding of preplaced powder on mild steel to increase the wear resistance of Mild steel. A constant CO2 laser beam of $2.5 \mathrm{~kW}$ at a speed of $2.5 \mathrm{~mm} / \mathrm{s}$ was implemented to remelt the powder. The author indicated that the laser cladding VC-Cr7C3 obtained a greater Hardness than the substrate. Hence, the clad coating exhibited wear-resistant ability 4 times higher than the substrate [55].

S. Luyckx developed WC-VC-Co and WC-Co powder feedstock and coatings through $\mathrm{HVOF}$ processes of equal weight fraction of $\mathrm{Co}$ and investigated with micro-examination, wear resistance and abrasion resistance. The author found that the existence of $(\mathrm{W}, \mathrm{V}) \mathrm{C}$ grains, which are not only resistant to abrasion but also to fracture due to their hardness and fine size. In relation to the above-mentioned variables, the greater moist abrasion resistance of the $\mathrm{WC}-\mathrm{VC}-\mathrm{Co}$ coatings was due to the reduced volume fraction of the Co binder stage at an equal mass ratio. In moist abrasion, the binder stage is lost through both corrosion and abrasion, resulting in more carbide grain fall-out, resulting in greater wear resistance when the Co proportion on the wearing surfaces is smaller [56].

X.S.Fan researched the microstructure of VC coating on AISI H13 and 9Cr18 Steel material through a thermo-reactive deposition method at $9200 \mathrm{C}$ for 4 hours. The author discovered equiaxed grains with $0.27 \pm 0.12 \mu \mathrm{m}$ average size and elongated grains with $1.56 \pm 0.54 \mu \mathrm{m}$ average size parallel and $0.69 \pm 0.09 \mu \mathrm{m}$ average size perpendicular to the coating/substrate interface in VC Coating on AISI H 13 and 9Cr18steel respectively. The author found that the grain morphology in the area adjacent to the substrate was susceptible to carbon activity in substrates and therefore nucleation density and grain growth rate in the initial state. It would form elongated grains with a comparatively low carbon activity. Increased carbon activity substituted elongated grains with equiaxed grains [57].

Fang-fang used non-reactive magnetron sputtering to prepare VC / Ni multilayer coatings. By ball-on-plate dry sliding tests, the author investigated, mechanical properties and tribological behavior of the layer developed and carried out a thorough microscopic examination of the worn faces. The author noted that the coatings had a friction coefficient of $\sim 0.6$ and wear rates of $10-15 \mathrm{~m} 3 / \mathrm{N}$ m which were reduced by one order of magnitude compared to the M2 tool steel. By this study, The author found that adequate hard ceramic layer thickness was needed to optimize the wear resistance of nanoscale multilayer ceramic-metal layer [58].

Chen Wang developed multilayer Fe / VC coatings with a fixed bilayer (almost $=8 \mathrm{~nm}$ ) and varying Fe fraction (almost 0.6 to 0.9 ) on Si substrates by the sputtering method of DC magnetron. The author studied the coatings phase and microstructure at nanoscales by using X-ray Diffraction techniques and TEM techniques. The hardness of all Fe / VC coatings was recorded to be proportionately the same as 16.7 $\mathrm{Gpa}$, which is equivalent to 8.5 percent of the average elastic module of Fe / VC coatings, and the author also discovered that $\mathrm{Fe} / \mathrm{VC}$ multilayer coating with a 90 percent $\mathrm{Fe}$ had nearly double the toughness of the fracture as other Fe / VC coatings[59].

Kong Dejun, placed VC (vanadium carbide) coating on Cr12MoV cold-worked steel using anhydrous borate (thermal diffusion) method, FeV50, FeSi45 as the primary components. The author used SEM, XRD, XPS and EDS techniques for characterization of microstructures and chemical compositions respectively. The author found that the $\mathrm{VC}$ coating interface consists of mutual diffusion between $\mathrm{V}, \mathrm{C}$, and $\mathrm{Fe}$, which is the primary metallurgical combination mechanism at the Vanadium Carbide coating interface [60]. 


\section{Conclusion:}

Thermal Spray process is globally accepted for producing coatings to enhanced product life, improve wear resistant, corrosion resistant, explosion resistant, etc. in this review we study the various thermal spray process being used for developing a coating with different capacities. As compared with another thermal spray process High-Velocity Oxygen Fuel (HVOF) Spray method results in an extremely dense, well-bonded coating with less porosity level. From the study of the coating materials, it is revealed that many feedstock materials ranges are available in the market for the HVOF process, it requires more focus on the development of the complex carbide (Binary and Tertiary carbide) coating by HVOF process.

\section{REFERENCES}

1. B. Singh, D. Puri, and S. Prakash, "Characterisations of plasma-sprayed and laser remelted NiCrAlY bond coats and $\mathrm{Ni} 3 \mathrm{Al}$ coatings on boiler tube steels," Mater. Sci. Eng., vol. 368, pp. 149-158, 2004.

2. G. S. Upadhyaya, "Materials science of cemented carbides $\square$ an overview," Mater. Des., vol. 22, no. December 2000, pp. 483-489, 2001.

3. H. E. Exner, "Physical and chemical carbides," no. 4, 1979.

4. B. Roebuck and E. A. Almond, "Deformation and fracture processes and the physical metallurgy of WC-Co hard metals," 90 Int. Mater. Rev. 1988, vol. 33, no. 2, pp. 90-112, 1988 .

5. C. C. Berndt, "IFTHSE Global 21: heat treatment and surface engineering in the twenty-first century Part 10 - Thermal spray coatings : a technology review," Int. Heat Treat. Surf. Eng., vol. 4, no. 1, pp. 7-13, 2010.

6. J. R. Davis, "Thermal Spray Technology Edited by," 2004.

7. S. Fantassi, M. Vardeue, A. Vardelle, and P. Fauchais, "Influence of the Velocity of Plasma-Sprayed Particles on Splat Formation," J. Therm. Spray Technol., vol. 2, no. December, pp. 379-384, 1993.

8. T. S. Films and M. Engineering, "THE RELATIONSHIP BETWEEN THE MECHANISM OF FORMATION, MICROSTRUCTURE AND PROPERTIES OF PLASMA- SPRAYED COATINGS*," Thin Solid Films, vol. 83, pp. 297-310, 1981.

9. A. S. M. Ang, C. C. Berndt, M. Dunn, M. L. Sesso, and S. Y. Kim, "Modeling the coverage of splat areas arising from thermal spray processes," J. Am. Ceram. Soc., vol. 95, no. 5, pp. 1572-1580, 2012.

10. P. Fauchais, G. Montavon, and G. Bertrand, "From Powders to Thermally Sprayed Coatings," vol. 19, no. January, pp. 56-80, 2010.

11. H. L. D. V. Lovelock, "Powder/ processing Structure Relationships in WC-Co Thermal Spray Coatings: A Review of the Published Literature," J. Therm. Spray Technol., vol. 7, no. September, pp. 357-373, 1998.

12. A. S. M. Ang and C. C. Berndt, "A review of testing methods for thermal spray coatings," Int. Mater. Rev., vol. 59, no. 4, pp. 179-223, 2014

13. P. Cheang and K. A. Khor, "Influence of Powder Characteristics on Plasma-Sprayed Hydroxyapatite Coatings," vol. 5, no. September, pp. 310-316, 1996.

14. P. S. Babu, D. S. Rao, G. V. N. Rao, and G. Sundararajan, "Effect of Feedstock Size and its Distribution on the Properties of Detonation Sprayed Coatings," vol. 16, no. June, pp. 281-290, 2007.

15. S. Jiansirisomboon, K. J. D. Mackenzie, S. G. Roberts, and P. S. Grant, "Low-pressure plasma-sprayed $\mathrm{Al} 2 \mathrm{O} 3$ and $\mathrm{Al} 2 \mathrm{O} 3 / \mathrm{SiC}$ nanocomposite coatings from different feedstock powders," vol. 23, pp. 961-976, 2003.

16. J. Wang, E. H. Jordan, and M. Gell, "Plasma Sprayed Dense MgO-Y 2 O 3 Nanocomposite Coatings Using Sol-Gel Combustion Synthesized Powder," vol. 19, no. 3, pp. 873-878, 2010.

17. M. Vardelle, A. Vardelle, P. Fauchais, K. Li, B. Dussoubs, and N. J. Themelis, "Controlling Particle Injection in Plasma Spraying," vol. 10, no. June, pp. 267-284, 2001

18. S. S. and Z. H. Vaidya A, Streibl T, "A comparative diagnostic analysis of morphologically different YSZ powders," in Int. Thermal Spray Conf., pp. 400-406.

19. P.Cheang and K.A.Khor, "THERMAL SPRAYING OF HYDROXYAPATITE (HA) COATINGS: POWDER FEEDSTOCK,” J. Mater. Process. Technol., vol. 48, pp. 429-436, 1995.
20. R. M. Watt, "The science and engineering of thermal spray coatings," Composite Structures, vol. 34, no. 1. p. 117, 1996.

21. Schoop MU, "An improved process of applying deposits of metal or metallic compounds to surfaces," 1912.

22. T. Asian, T. Spray, S. Y. Hwang, H. Dong, S. Korea, and N. Company, "The Current Status of Thermal Spraying in Asia," J. Therm. Spray Technol., vol. 17, no. November 2006, pp. 5-13, 2008.

23. The Linde Group, "Flame solutions. ®," Lindoflamm, pp. 1-12, 2010.

24. S. K. Rakesh Kumar, "thermal spray coating: a study,” Int. J. Eng. Sci. Res. Technol., vol. 7, no. 3, pp. 610-617, 2018.

25. S. H. and L. H. Poorman RM, "Method and apparatus utilizing detonation waves for spraying and other purposes," 2,714,563, 1955.

26. L. Pawlowski, The Science and Engineering of Thermal Spray Coatings, Second ed. John Wiley \& Sons, Ltd, 2008.

27. G. Sundararajan, K. U. M. Prasad, D. S. Rao, and S. V Joshi, "A Comparative Study of Tribological Behavior of Plasma and D-Gun Sprayed Coatings under Different Wear Modes," vol. 7, no. June, pp. 343-351, 1998

28. R. C. T. Jr and R. C. Tucker, "Structure-property relationships in deposits produced by plasma spray and detonation gun techniques Structure-property relationships in deposits produced by plasma spray and detonation gun techniques," vol. 725, no. 1974, 1985.

29. K. Niemi, P. Vuoristo, and T. M, "Properties of Alumina-Based Coatings Deposited by Plasma Spray and Detonation Gun Spray Processes," vol. 3, no. June, pp. 199-203, 1994.

30. M. L. Thorpe, "A Pragmatic Analysis and Comparison of HVOF Processes," J. Therm. Spray Technol., vol. 1(2), no. June, pp. 169-178, 1992.

31. S. Kamnis and S. Gu, "3-D modeling of kerosene-fuelled HVOF thermal spray gun," Chem. Eng. Sci., vol. 61, pp. 5427-5439, 2006.

32. J. Lesage and D. Chicot, "Role of residual stresses on interface toughness of thermally sprayed coatings," vol. 415, pp. 143-150, 2002

33. G. Bolelli et al., "Surface \& Coatings Technology Residual stresses in HVOF-sprayed ceramic coatings," vol. 202, pp. 4810-4819, 2008.

34. M. P. Planche, J. F. Coudert, and P. Fauchais, "Velocity Measurements for Arc Jets Produced by a DC Plasma Spray Torch,” Plasma Chem. Plasma Process., vol. 18, no. 2, pp. 263-283, 1998.

35. E. Pfender, "Plasma jet behavior and modeling associated with the plasma spray process," Thin Solid Films, vol. 238, pp. 228-241, 1994.

36. D. K. Das, R. Sivakumar, and D. Metallurgical, "Modelling of the temperature and the velocity of ceramic powder particles in a plasma flame-II. zirconia," Acta Met. mater., vol. 38, no. 11, pp. 2193-2198, 1990

37. S. Zhu and B. Xu, "High-Performance Ceramic Coatings Sprayed via Novel Supersonic Plasma Spraying System,” vol. 283, no. 2005, pp. 1203-1206, 2007

38. H. Tahara and Y. Ando, "Study of titanium nitride deposition by supersonic plasma spraying," vol. 83, pp. 98-101, 2009.

39. Schoop MU, "Apparatus for spraying molten metal and other fusible substances," 1,133,507, 1915.

40. L. D. Z. and X. Y. S. R.Li, D.Y. He, Z. Zhou, "High-temperature corrosion behavior of wire arc sprayed Fe based coatings," Surf. Eng., vol. 30, no. 8, pp. 573-579, 2014.

41. N. N. and S. M. Alkhimov AP, Papyrin AN, Kosarev VF, "Gas-dynamic spray method for applying a coating," 5,302,414, 1994.

42. R. C. Dykhuizen and M. F. Smith, "Gas Dynamic Principles of Cold Spray," J. Therm. Spray Technol., vol. 7, no. March, pp. 205-212, 1998.

43. R. C. Dykhuizen, M. F. Smith, D. L. Gilmore, R. A. Neiser, X. Jiang, and S. Sampath, "Impact of High-Velocity Cold Spray Particles," J Therm. Spray Technol. Vol., vol. 8, no. December, pp. 559-564, 1999.

44. T. H. Van Steenkiste et al., "Kinetic spray coatings," vol. 111, pp. 62-71, 1999.

45. H. Singh, B. Singh, and S. Prakash, "Mechanical and microstructural properties of HVOF sprayed WC - Co and $\mathrm{Cr} 3 \mathrm{C} 2-\mathrm{NiCr}$ coatings on the boiler tube steels using LPG as the fuel gas," vol. 171, pp. 77-82, 2006.

46. H. J. C. Voorwald, R. C. Souza, W. L. Pigatin, and M. O. H. Cioffi, "Evaluation of WC $-17 \mathrm{Co}$ and $\mathrm{WC}-10 \mathrm{Co}-4 \mathrm{Cr}$ thermal spray coatings by HVOF on the fatigue and corrosion strength of AISI 4340 steel," vol. 190, pp. 155-164, 2005.

47. H. L. Tian et al., "Tribological behavior of a self-lubricated GO / WC 12Co thermal spray coating," Surf. Eng., vol. 0, no. 0, pp. 1-9, 2017. 
48. X. Ding, X. Cheng, X. Yu, C. Li, C. Yuan, and Z. Ding, "Structure and cavitation erosion behavior of HVOF sprayed multi-dimensional WC 10Co4Cr coating," Trans. Nonferrous Met. Soc. China, vol. 28, no. 3, pp. 487-494, 2018.

49. O. Ali, R. Ahmed, N. H. Faisal, N. M. Al-anazi, Y. O. Elakwah, and M. F. A. Goosen, "Nanoindentation Evaluation of Suspension Thermal Sprayed Nanocomposite WC-Co Coatings," vol. 735, pp. 225-229, 2017.

50. M. S. Lamana, A. G. M. Pukasiewicz, and S. Sampath, "Influence of cobalt content and HVOF deposition process on the cavitation erosion resistance of WC-Co coatings," Wear, vol. 398-399, no. May 2017, pp. 209-219, 2018

51. V. Katranidis, S. Gu, D. C. Cox, M. J. Whiting, and S. Kamnis, "FIB-SEM Sectioning Study of Decarburization Products in the Microstructure of HVOF-Sprayed WC-Co Coatings," J. Therm. Spray Technol., pp. 1-11, 2018.

52. M. Aghaie-Khafri and F. Fazlalipour, "Vanadium carbide coatings on die steel deposited by the thermo-reactive diffusion technique," J. Phys. Chem. Solids, vol. 69, no. 10, pp. 2465-2470, 2008.

53. S. V. Shah and N. B. Dahotre, "Laser surface-engineered vanadium carbide coating for extended die life," J. Mater. Process. Technol., vol. 124, no. 1-2, pp. 105-112, 2002.

54. X. S. Fan, Z. G. Yang, C. Zhang, Y. D. Zhang, and H. Q. Che, "Surface \& Coatings Technology Evaluation of vanadium carbide coatings on AISI H13 obtained by thermo-reactive deposition/diffusion technique," Surf. Coat. Technol., vol. 205, no. 2, pp. 641-646, 2010

55. Q. Wu, W. Li, N. Zhong, W. Gang, and W. Haishan, "Microstructure and wear behavior of laser cladding VC-Cr7C3ceramic coating on steel substrate," Mater. Des., 2013.

56. S. Luyckx and C. N. Machio, "Characterization of WC-VC-Co thermal spray powders and coatings," Int. J. Refract. Met. Hard Mater., vol. 25, pp. 11-15, 2007.

57. X. S. Fan, Z. G. Yang, Z. X. Xia, C. Zhang, and H. Q. Che, "The microstructure evolution of VC coatings on AISI H13 and $9 \mathrm{Cr} 18$ steel by thermo-reactive deposition process," J. Alloys Compd., 2010.

58. F. Ge, X. Zhou, F. Meng, Q. Xue, and F. Huang, "Tribological behavior of $\mathrm{VC} / \mathrm{Ni}$ multilayer coatings prepared by non-reactive magnetron sputtering," Tribol. Int., 2016.

59. C. Wang, J. M. Pureza, Y. Yang, and Y. W. Chung, "Investigation of hardness and fracture toughness properties of Fe/VC multilayer coatings with coherent interfaces," Surf. Coatings Technol., 2016.

60. K. Dejun, W. Jinchun, and G. Haoyuan, "XPS and EDS Analysis of VC Coatings Prepared by TD Process,” Rare Met. Mater. Eng., 2016.

\section{AUTHORS PROFILE}

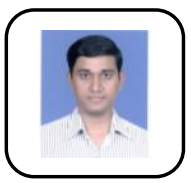

Prof. D K Patel, presently working as Assistan Professor in Mechanical Engineering, L D College of Engineering, Ahmedabad he completed his UG in Mechanical Engineering from Bhavnagar University, Bhavnagar, and PG in Welding Technology from the MSU Baroda. He has completed two-year tenure as welding engineer with L \& T Hazira works; Surat in 2009.He was also associated with Indus Institute of Engineering \& Technology as an assistant professor from 2009 to 2011 . He has teaching and research experience more than 10 years. He has published 2 papers in International journal and 1 paper in national journal. He guided $1 \mathrm{ME}$ thesis in the field of Plasma Welding. Currently, he is pursuing PhD in the field of surface coating from Gujarat Technological University, Ahmedabad.

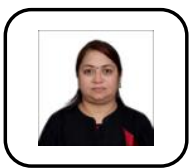

Dr. Pina Bhatt with a vision of outcome base education currently working as a Principal of Aditya Silver Oak Institute of Technology, Ahmedabad, Gujarat. She has more than 20 years of Academic and Administrative Experience. During her tenure at GTU and SVBIT she has established two center of Excellence of welding and I-os respectively.

Dr Pina Bhatt was awarded a PhD in Mechanical Engineering from RK University and her research was based on Hard Coating for various Industrial Applications. She got Master of Engineering Degree from Gujarat Technological University in the Field of Cryogenic and Bachelor of Engineering from North Gujarat University.

She has published more than 15 National and International Papers in reputed Journal as well as presented research papers in various Conference.
She is Students Chair of Western India Chapter of AHSRAE and also served as Chapter Working Committee of Indian Society of Heating Refrigeration and Air Conditioning Ahmedabad Chapter for more than three years. She is also active member of IIW, ICC and ASM.

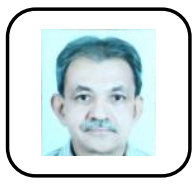

Mr. Ragesh N Bateriwala, presently he served as managing director at Keepsake Engineering Consultancy Pvt Ltd. He did his UG in mechanical from Gujarat University, Ahmedabad. He is Past president at ASM international Gujarat Chapter. He runs a Centre of Excellence -Welding and provided training to more than 450 industries members and students. He has more than 50 years of Industries and Research Experience in the field of welding and thermal spray coating. Currently, he is involved with research of solar absorption coatings, effluent treatment products responsible for cladding procedure qualification of satellite (cobalt-base) hard-facing. 